\title{
Forming effective relationships between academia and the medical devices industry with a focus on launching a smart heart valve prosthesis for pediatric patients
}

\author{
Albert R. Liberski ${ }^{i^{*}}$ D, Jonathan T. Butcher ${ }^{2}$, Zbigniew Nawrat ${ }^{3}$, Tal Golesworthy ${ }^{4}$ and Dena Ahmed Al Thani ${ }^{5}$
}

\begin{abstract}
Background: This article presents examples of how to utilize the research output, to initiate academia-industry interaction, with the ultimate task of launching a new product: a smart heart valve prosthesis for pediatric patients. The article summarizes our efforts in a way that may also be informative to researchers working in fields other than medical devices development. Our task is not to provide a step-by-step guide, but rather to create inspiration, also by describing differences in expectations of business and academic entities.
\end{abstract}

Methods: We analyzed market reports, surveyed the scientific literature and conducted interviews with the key players in the field of medical devices. We also obtained a feedback from clinicians, academia and industry-related researchers, technology transfer centres, representatives of public organization and the creators of legislation.

Results: We have obtained and reported the definitive answers that together constitute a critical review of strategies that should be used by researchers who seek to commercialize the outputs of their research.

Conclusion: As a result of our investigation, we discovered that the commercialization of research is a complex process, which in some critical aspects does not depend solely on the researcher himself. The most promising ideas, supported by strong experimental evidence, can simply be overlooked by industry representatives, without the proper support of institutions such as a technology transfer centre. Besides, the involvement of scientists in a business project takes them, at least temporarily, outside the regular academic environment, which may cause discomfort and pose a risk to the career path. The limitation to be addressed is the reluctance to report the unsuccessful attempts, which should be considered a legitimate educational experience that ultimately leads to improvement.

Keywords: Heart valve prosthesis, Pediatric patients, Research commercialization, Intellectual property legislation, Medical devices, In-situ tissue engineering, Manufacturers of large medical devices, Academic technology transfer centres, Clinicians, Communication

\section{Background}

Bata Corporation had implemented mass production methods in the footwear industry years before Henry Ford revolutionized automotive production [1]. In 1932, two representatives of Bata were tasked with looking for business options in North Africa. They sent two different messages. The first representative wrote: "Nobody uses shoes

\footnotetext{
*Correspondence: chemikszkot@gmail.com

${ }^{1}$ Division of Sustainable Development, College of Science \& Engineering, Hamad Bin Khalifa University, P.O. Box 34110, Education City, Doha, Qatar Full list of author information is available at the end of the article
}

here. I don't see any sales opportunities. I'm coming back home." The second message was: "Everyone is barefoot. A great business opportunity! Send shoes as soon as possible." This example shows that people exposed to the same experience can come to entirely different conclusions. In this light, we strongly recommend that all readers look over the entire text. However, we have prepared the following table, containing the key conclusions from interviews, to increase the involvement of readers from the industry. As an anonymous contributor substantively explains, industry researchers are always encouraged by

(C) The Author(s). 2019 Open Access This article is distributed under the terms of the Creative Commons Attribution 4.0 International License (http://creativecommons.org/licenses/by/4.0/), which permits unrestricted use, distribution, and 
senior management to move away from scientific projects (in the interest of saving time and the constant challenge to meet strict deadlines in organizations). Because of that, a manuscript covering more than 40 pages may be overlooked, and its critical points may be omitted. The summary (see Table 1) allows the industry employees to understand this paper's essence and to remember these important issues when assessing innovative technologies with a partner from the academic community.
The corresponding author of this article is a member of the research team which focuses on developing a bioresorbable aortic heart valve (HV) prosthesis. During the last several years, a series of applicable solutions were proposed, some of which are summarized in the research articles [2-7]. Briefly, the solutions developed in the course of the research conducted in Qatar included fabrication of the smart scaffold (See Fig. 1) which would be eventually replaced by patients' own cells in order to

Table 1 A brief summary of conclusions drawn from the interviews carried on with academic and industry representatives. The initials are used instead of names

\begin{tabular}{|c|c|c|}
\hline Conclusion & $\begin{array}{l}\text { Feedback } \\
\text { of: }\end{array}$ & $\begin{array}{l}\text { Refer to } \\
\text { paragraph }\end{array}$ \\
\hline $\begin{array}{l}\text { Obtain patent for the solution you are going to offer to industry partner. Without a patent, there will be no interest in } \\
\text { the idea. }\end{array}$ & $\begin{array}{l}\mathrm{ZMH}^{\mathrm{a}} \\
\mathrm{JTB}^{\mathrm{a}} \\
\mathrm{RJK}^{\mathrm{b}} \\
\mathrm{SJR} \mathrm{R}^{\mathrm{b}}\end{array}$ & $\begin{array}{l}3.1 .1 \\
3.1 .2 \\
3.2 .1 \\
3.3 .1\end{array}$ \\
\hline Work out the confidence about the solution you propose. Openly discuss obstacles and how to mitigate them. & $S J R^{b}$ & 3.3.1. \\
\hline $\begin{array}{l}\text { Time is strictly regulated commodity for the industry. The ideas that can quickly develop into the product would be } \\
\text { preferred. }\end{array}$ & $S J R^{b}$ & 3.3.1. \\
\hline Find out what features are critical for industry and focus on them while presenting an idea. & $S J R^{b}$ & 3.3.1. \\
\hline $\begin{array}{l}\text { Launching a new medical product is costly and risky but a strategic effort, thus the involvement of top management } \\
\text { can be expected. }\end{array}$ & $\begin{array}{l}S J R^{b} \\
Z N^{b}\end{array}$ & $\begin{array}{l}3.3 .1 \\
3.1 .3\end{array}$ \\
\hline Aim high in attempting to gain contacts with industry. The "lords of the time" are the executive directors. & $A R L^{a}$ & 2 \\
\hline Establish contacts by inviting industry representatives to provide lectures. & $S J R^{b}$ & 3.3.1. \\
\hline $\begin{array}{l}\text { Recruit the industry partner as a cofounder in the grant applications. This enables you to learn about the "real" } \\
\text { problems, which the industry is currently facing. }\end{array}$ & $\mathrm{ZMH}$ & 3.1.1 \\
\hline $\begin{array}{l}\text { Be ready to sacrifice the progress of your academic carrier. The industry partner will need your feedback, loyalty, and } \\
\text { dedication. }\end{array}$ & $\mathrm{ROK}^{\mathrm{a}}$ & 3.4 \\
\hline $\begin{array}{l}\text { Tone down your enthusiasm - your conclusions are only the prelude to the complex process of launching a new } \\
\text { medical device. }\end{array}$ & $\begin{array}{l}J T^{a}{ }^{\prime} \\
S J R^{b^{\prime}}\end{array}$ & $\begin{array}{l}3.1 .2 \\
3.3 .1\end{array}$ \\
\hline $\begin{array}{l}\text { Communication via Academic Technology Transfer Centers (ATTCs) is the most efficient way to announce a new } \\
\text { solution to the industry partner. The efficiency of internet communication platforms launched by some corporation is } \\
\text { disputable. }\end{array}$ & $\begin{array}{l}J T^{a} \\
S J R^{b}\end{array}$ & $\begin{array}{l}3.1 .2 \\
3.3 .1\end{array}$ \\
\hline ATTCS are in charge of IP protection. & $\mathrm{ROK}^{\mathrm{a}}$ & 3.4 \\
\hline $\begin{array}{l}\text { Let ATTC support you in fulfilling academic duties while your efforts are needed on the project with the industry } \\
\text { partner. }\end{array}$ & $\mathrm{ROK}^{\mathrm{a}}$ & 3.4 \\
\hline ATTCs are essential to establishing and maintaining contact with the executive management in corporations. & $\begin{array}{l}\text { RJK } K^{b} \\
\text { ROK }^{\mathrm{a}}\end{array}$ & $\begin{array}{l}3.3 .1 \\
3,4\end{array}$ \\
\hline Promote your solution with research articles, conference presentation and networking (consider internet positioning). & $\begin{array}{l}\mathrm{JTB}^{\mathrm{a}} \\
\mathrm{ZMH}^{\mathrm{a}} \\
\mathrm{RR}^{\mathrm{b}}\end{array}$ & $\begin{array}{l}3.1 .2 \\
3.1 .1 \\
3.3 .2\end{array}$ \\
\hline Solution validated in the animal model could increase a chance to trigger the attention of the industry. & $\mathrm{ARL}^{\mathrm{a}}$ & 4. \\
\hline Build a multidisciplinary team of experts to cross-check and improve your ideas. & $Z N^{b}$ & 3.1 .3 \\
\hline Implement your solution locally to prove its feasibility. & $Z N^{b}$ & 3.1 .3 \\
\hline Confirm the commercial advantages of your solution. & $A R L^{a}$ & Background \\
\hline $\begin{array}{l}\text { Based on the conflict of interest section in publications, find and canvass the clinicians that actively collaborate with } \\
\text { industry. }\end{array}$ & $\begin{array}{l}\mathrm{ARL}^{\mathrm{a}} \\
\mathrm{ZMH}^{\mathrm{a}} \\
\mathrm{JTB}^{\mathrm{a}}\end{array}$ & $\begin{array}{l}4 \\
3.1 .1 \\
3.1 .2\end{array}$ \\
\hline $\begin{array}{l}\text { Avoid the "Hegel's-struggle for recognition", the industry battles for income. The motivation of helping patients is a } \\
\text { common ground. }\end{array}$ & $\mathrm{RJK}^{\mathrm{b}}$ & 3.3 .1 \\
\hline Follow the regulations of and respect regulatory bodies. They protect the public. & $\mathrm{ROK}^{\mathrm{a}}$ & 3.4 \\
\hline If rejected by the industry, apply your solution for highly customized, personalized health care. & $\mathrm{GT}^{\mathrm{b}}$ & 3.1 .4 \\
\hline
\end{tabular}




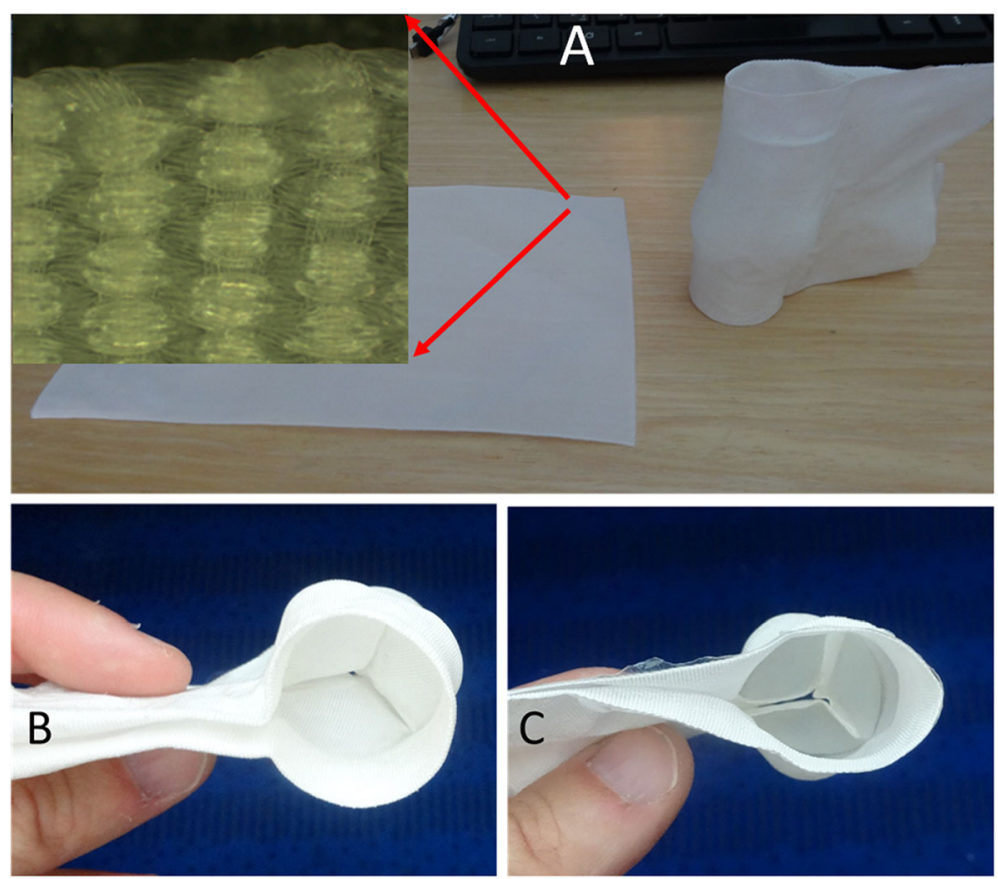

Fig. 1 Processing 2D, polycaprolactone (PCL) fabric (a) into three dimensional and functional heart valve including sinuses and leaflets, for native valve replacement $(\mathbf{b} \& \mathbf{c})$. Red arrows indicate the close-up view of the fabric, the plot of the single thread is visualized

yield functional organ growth. The concept was described in multiple scientific reports [2] and successes in the animal model were widely discussed [8-10]. Our added value was basing the scaffold manufacturing process on textile technology and using the advantages of the fabric architecture, which was discussed in depth elsewhere [4, 7].

The problem. The project arouses the interest of investment funds, which are ready to bear the costs of animal testing. However, one pivotal question remains unaddressed: in the case of successful animal testing, with whom is the team going to continue the project towards commercialization?

What do we know? To confirm the commercial potential of the smart scaffolds, we referred to scientific literature [11-20], and market reports [21-27]. Both sources confirmed that all market available alternative HV prostheses do not grow with the patient, have limited longevity (biological valves $[19,20]$ ) or cause thrombosis if not accompanied with continuous medication (synthetic valves [19]). This constitutes the strong premise that smart scaffold technology could compete with existing devices. Moreover, we confirmed that marketizing a HV prosthesis is a highly regulated $[26,28]$ and expensive process [29]. Since HV prostheses are medical devices and their usage is supervised by multiple bodies (for example, the Food and Drug Administration in the USA), it becomes apparent that only large medical device manufacturers (LMDMs) have sufficient resources to launch the product. However, we also found that developing relationships with LMDMs is not an easy task.

To target the patients that may benefit from the smart scaffold the most, we studied the situation in Poland, which is a member of EU, has approximately 37 million inhabitants and neighbours the strongest EU economy Germany. Because the Qatar population is about 2 million including expatriates, the consideration of a larger country was justified. With this in mind, we contacted the Polish institution Narodowy Fundusz Zdrowia (NFZ) which is responsible for financing the health service nationwide. With their extensive assistance a comprehensive report was obtained [30] showing HV prosthesis usage in Poland. The data summarizes years 2016-2017 and includes: the number and type of HV prosthesis implanted, the number of implantations in each regional center of health, the proportion of HV prostheses implemented using the catheter method, the number of $\mathrm{HV}$ prostheses implemented in pediatric patients and prices for a variety of procedures covered under the national health system. Importantly, NFZ does not impose the exact valve prosthesis that must be used by medics. Instead, the entire procedure is financed, so clinicians may choose the most patient-relevant and financially effective procedure. For example, the implantation of an aortic heart valve in an adult patient costs 90,000PLN (24,000 USD) and includes $36 \mathrm{~h}$ of intensive post-operational care. In 2016 and 2017, NFZ financed about 6300 procedures of $\mathrm{HV}$ implantation annually. Sixty percent of 
implanted prostheses were biological, while the rest were synthetic. There are 35 hospital centres in which procedures took place; the leading one is The John Paul II Specialist Hospital in Kraków (690 procedures annually). The third largest supplier of this procedure in Poland is the Silesian Center for Heart Diseases in Zabrze (440 procedures annually). The Zabrze population is about four times lower than Krakow. However, Zabrze is also an important hub for cardiac research which explains a large number of procedures carried out there. In 2016, 862 transcatheter procedures were carried out, while in 2017 the number increased to 1027 cases. Regarding patients below 18 years of age in this 2 -year period -10 procedures were carried out for patients aged 0-4, 33 for patients aged 5-10, and 49 for patients aged 11-18.

What we do not know? Equipped with strong evidence on the commercial value of our solution, we encountered the next challenge: how to obtain feedback from LMDMs to demonstrate to investors how and with whom the project may develop after succeeding with animal tests and patenting.

What did we do to find a solution? Since the obvious way to proceed was not identified, we sought feedback from more advanced academic researchers which is presented in the results section. We also managed to contact LMDMs to ascertain their method of operating when it comes to academia-industry relationships. It should be emphasised that during the interview, we did not present the solution developed but instead focused only on obtaining feedback on how to interact efficiently.

Why it may be interesting for others? This article is meant to benefit both scientists and industrial partners and it summarizes the steps required for scientists to present their solutions to industries and obtain feedback. Due to the nature of our scientific interest, we focus on HV prosthesis manufacturers, but this could also be beneficial to other fields.

\section{Methods}

When considering the commercialization of the outputs of the research projects, the following question arises: "how do we find a reliable industry partner to whom the given solution would be beneficial?" The attempt to answer this question by searching in general scientific literature is futile since this inquiry is more business in nature. On the other hand, there are written reports including case studies of successful business entities; however, very little can be found on the research/business interactions. For example, a comprehensive report on Hewlett-Packard (Palo Alto, CA, USA), (HP) does not inform on scientific collaborations, despite the fact that HP has Research and Development (R\&D) division and strongly depends on research and innovations [31]. Taking this into account, a questionnaire was conducted on prominent scientists, surgeons, and engineers, in order to determine their thoughts on the dilemma of research commercialization. The questionnaire included a description of the concept behind the publication and 30 questions divided into 3 sections, see ref. [32] for examples of the distributed form. The questionnaire was slightly customized depending if industry, an academia, or clinic representative was invited to provide the feedback. The first section of the questionnaire was designed to learn the details about the entity represented by the interviewee. The second one enabled us to learn more about their collaboration with external entities, researchers, clinicians. The last section was designed to let the interviewee explain what in his/her opinion is the most efficient way to initiate collaboration, and what are the requirements and expectations regarding collaboration with an entity or a person. Importantly - some interviewees chose to strictly adhere to the questions, while others preferred to speak freely. Both ways of communication were equally welcomed.

This method of scientific communication was previously implemented in the article about the optimal shape of the HV prosthesis [2]. Since our academic research was conducted in the area of smart HV prostheses, we also contacted the main stakeholders: Abbott (IL, USA), Boston Scientific (Maple Grove, MN, USA), Medtronic (Minneapolis, MN, USA) and Edwards Lifesciences (Irvine, CA, USA). We sent more than 100 emails (see example [32]) and received three responses to our interview invitation, but not from any LMDMs. Through telephone calls, we managed to obtain feedback from Edwards and Medtronic, no response from Boston Scientific and rejection from Abbott, confirmed in several emails. Moreover, we received a comprehensive report via email from NFZ [33] which summarized the usage of HV prostheses in Poland [30]. The feedback from the interviews was transcribed and, along with the survey results, was published after revision and approval of the participants.

Since it may be beneficial to the scientific community, we decided to supplement the methods section with a short discussion on the difficulties encountered. Approaching LMDMs is challenging, firstly due to strict hierarchical structure and confidentiality of employee conducts. It is natural that whenever asked about company strategies (here $R \& D$ ) only the top management in a corporation can talk freely without the threat of disclosing confidential data. Fortunately, we were able to find allies who, from their position in the corporation, supported us in contacting the public relations departments and managers. The second source of the problem is that obviously for LMDMs, the highest priority interactions are with the patients who are seeking help. Many communication channels $[34,35]$ are simply set to help 
people. Therefore, emails that are not strictly related to health can be overlooked. Even when passing all filters and contacting the decision-makers, the leaders of the market may simply prefer the status quo, with a minor interest in new technologies that may become the thread for the current business model. Altogether, it should be emphasized that when it comes to LMDMs, email as a primary communication tool is inefficient. It was only the support obtained thanks to direct telephone conversations that led to an aimed interaction.

\section{Results}

\section{Feedback from clinicians, researchers and innovators} Prof. Ziyad M Hijazi, MD, professor of Pediatrics\& Medicine, Weill Cornell medicine chair, Department of Pediatrics, director, Sidra heart center, editor-in-chief, journal of structural heart disease, Sidra medicine

Professor Hijazi is an interventional cardiologist who specializes in treating congenital and structural heart disease in both children and adults. He is a pioneer in the nonsurgical repair of congenital and structural heart defects. Professor Hijazi is very prolific, with more than 330 peerreviewed published articles, 9 books, and over 60 book chapters. His major area of interest is in the development of techniques and catheters/devices to help treat or cure congenital and structural cardiac disease without openheart surgery. Back in 1991, Professor Hijazi started working on stents and balloons with a company called Numed, based in New York. With them, he developed Z-med balloons [36] and the Angiostent [37]. Currently, Professor Hijazi is working with Venus Medtech (Hangzhou, China) to develop a pulmonic valve and with Colibri Heart Valve (Broomfield, CO, USA) to develop other pulmonic and aortic valves. In addition, the portfolio of medical devices developed, or co-developed by Professor Hijazi and his team, includes the Septostomy Balloon Catheter [38], ASD device closure $[39,40]$ and percutaneous pulmonary valves [41]. Since Professor Hijazi is a simultaneously successful scientist, interventionalist, researcher, innovator and educator, his interaction with LMDMs is well established. Usually, LMDMs initiate the contact and offer collaboration to develop a specific product for certain initiatives, under a non-disclosure agreement (NDA). Professor Hijazi has also worked with Edwards Lifesciences [42], as well as smaller companies, including Occlutech (Helsingborg, Sweden), Venus Medtech (Hangzhou, China), NuMED (Hopkinton, NY, USA) and Colibri Heart Valve (Broomfield, CO, USA). The interaction with all these entities was positive. In fact, the LMDMs were found to be key partners since they have the resources, power, and determination needed to enable progress. The collaboration with Edwards started in 2003 and was/is an especially good experience. Obviously, LMDMs must always refer to the business point of view, so their interest in supporting devices for adults was greater than for pediatric patients.

Retrospectively, the interest of LMDMs was triggered, primarily by a screening of scientific articles and conference meetings. Moreover, Professor Hijazi coordinated the large structural heart disease course, PICS/AICS [43] which also helped him to be recognizable by LMDMs. Professor Hijazi highlights the significant role of personal contacts in getting feedback from LMDMs. His first interaction with LMDMs was initiated by his mentor Professor Martin B. Leon. Professor Hijazi's effectiveness also comes from his kindness, his open-minded attitude and the curiosity with which he operates in a professional environment. Furthermore, his appearance in social and public media [44] assists with networking with and engaging the patients. However, dealing with regulatory bodies remains the challenge, since, above certain levels, formalities may hinder the progress of devices development. For example, in the USA, no study can be carried out without FDA approval. Often the requirements are strict and include a randomized trial. This is difficult with children, and sometimes may be viewed as unethical.

Professor Hijazi has had a positive experience in regard to LMDMs' attitudes towards intellectual property (IP) and remuneration. Careful studies on market requirements need to be conducted before a decision on commercialization is made for the given idea. Prepared partners agree on the value of the given solution and develop a fair consensus. The best way to be remunerated is via royalties on sales if the device is big. It seems to be an effective practice to approach only one LMDM with the given solution and wait and see the results, then if needed, move on to another. There are some very rare examples of purchasing technology that is not further developed. For example, NMT Medical sells intellectual property to W.L. Gore [45] which has so far not resulted in the implementation of medical products.

There are several keynotes that Professor Hijazi would like to share with individuals searching for feedback from LMDMs:

(I) Protect yourself. If it is your idea, ask the LMDM to sign a Non-Disclosure Agreement. Do not be greedy! You need them more than they need you. Be available all the time for their questions. Do not procrastinate.

(II) Good ideas that are not protected can and will be taken. This is the nature of the business.

(III)Go to meetings related to the topic of your interest. If you choose the correct conference, everyone you need will be there.

(IV)The patent will enforce your position in attempting to get feedback from LMDM. They move quicker if you have the IP. 
Assc. Prof. Jonathan T. Butcher, PhD, associate chair, director of undergraduate studies, Nancy E. and Peter C. Meinig School of Biomedical Engineering, Cornell University Professor Butcher is the author of over 100 scientific publications, indexed in PubMed. Many of them are directly related to heart valve development and heart valve tissue engineering (HVTE) [46]. Perhaps the most recognizable concept Professor Butcher is the use of additive manufacturing for the 3D printing of hydrogel-based heart valves. These efforts have inspired not only academic but also public interest [47]. According to Professor Butcher, the USA is one of several countries where interactions between science and industry are well-structured. Cooperation between universities and research institutions often bring ideas, technology, and further employment in the industrial sector. US academic institutions have increased efforts over the past decade to establish partnerships with industry for both to build technology to meet their needs but also to ensure their students are well-positioned to thrive in industry positions. One example is the University of Akron, which engages closely with industry to understand their needs, educates and trains students to be effective in meeting those needs as industry employees. Cornell University, with which Professor Butcher is affiliated, has also strengthened cooperation with the industry in recent years. Multiple initiatives have started to engage industry executives to explore shared goals and develop research partnerships. Researchers and students looking for industry engagement/development are equipped with several instruments. For example, one may use the services of the Cornell University Center for Technology Licensing, which both evaluates the commercial potential of innovations and coordinates high-quality patent applications. Each institution, including Cornell, has policies identifying how royalties from patents are distributed between the University, department, and inventors. At Cornell, the inventors receive one-third of the IP royalties. Considering that the University provides the resources for patenting and initial IP legal enforcement protection, the offer is very lucrative for the inventor. Professor Butcher has made several patent applications [48-50] and had two patents fully issued $[48,50]$. As Universities and faculty are normally not interested in running industrial businesses, these technology offices also work to license the technology to industry for further development.

Another facility available at many institutions like Cornell is an incubator that helps nucleate and grow startup companies. It will bring the idea closer to a marketrelevant product and attract the attention of industrial partners. Cornell University also provides the opportunity to apply for grants in which industrial collaborators have a financial contribution. In this case, financial involvement makes the industry very focused on observing the progress of the project from the very beginning. In this way, relationships are developed, and therefore presenting new ideas/achievements is not a problem.

Thanks to the comprehensive assistance of Cornell, Professor Butcher did not have to vigorously search for the attention of industrial partners on his own. However, he developed positive experiences with a small company delegated by LMDM to seek academic help in solving problems related to the production of medical devices. Based on a mutual understanding, the partners developed a research plan that included both scientific and industrial interest. The project was granted by LMDM and is growing well. It is significant that LMDMs outsource such initiatives to external entities. Researchers need to be careful when discussing technology and scientific discoveries with LMDMs, as without protection, this can amount to public disclosure that can imperil the patentability and thereby the value for both the LMDM and the researcher. This requires training and experience to draw the boundaries for which an NDA becomes a necessity. However, an NDA also has inherent drawbacks. Typically, an NDA is signed before the parties learn more about their mutual needs, problems, and expectations. Moreover, there are no attorneys at the discussion, so the researcher must tone down his/her enthusiasm. These discussions are almost always done by principal investigators, and any time there is IP that is filed, the discussions would involve tech transfer representatives as well. Universities are increasingly aware of these concerns and have developed internal training programs to educate researchers in best practices.

The safest way to present innovations in LMDMs is at first to issue a patent application. A professional agent usually develops a patent application in collaboration with the researcher and a legal company. At Cornell, the university tech transfer agents, usually have either an advanced science degree or a law degree, sometimes both.

Depending on the maturity of the technology and the amount of risk/reward in the market, larger industries are unlikely to purchase/license a patent until after it has been substantially validated. In the biomedical space, this, often depends on the results of clinical trials. The university usually needs to partner with venture firms to develop startups that can move the technology to stage 1 trials, then sell to a larger company for stage 2, etc. With non-medical products, it may take a shorter path, but the size of the potential market will influence how the university/faculty pursues development. Each institution is different, but options include licensing the technology back to the researcher to develop him/herself. Cornell, as well as other institutions, have developed increasingly complex conflict management policies and safeguards to protect both the faculty and institutions while enabling faculty to pursue these dual roles. 
Professor Butcher advises scientists to first leverage their own institutional resources. Optionally, they should look for local community incubators unless they have access to a network of resources/contacts in the industry. If there is no academic institution that is responsible, it falls on the scientist's shoulders to get the patent funded. Universities and incubators are in contact with the industry to help determine whether this is patentable.

\section{Professor Zbigniew Nawrat director of the Institute of Heart Prosthesis at Foundation of Cardiac Surgery Development, adjunct in the Department of Cardiac Surgery, Medical University of Silesia}

The Foundation of Cardiac Surgery Development (FCSD) is a non-governmental, non-profit organization, with a carefully planned and executed agenda. For 28 years the FCSD has achieved goals by conducting multidisciplinary research and production of medical devices. The mission of the FCSD is primarily to help patients who expect or have undergone heart transplant surgery. Because the motive of action is not the profit, the foundation deals with its intellectual property, accumulated knowledge, and expertise in a fundamentally different way than typical market entities. It is certain that if the scope of the foundation would be a financial profit, the venture would not achieve some of its successes. One example of a patientoriented attitude was retiring from patenting the heart chambers. This enabled the foundation to release the full potential of the biometric solutions developed [51, 52]. The idea and the need for the FCSD became apparent in 1985 when Professor Zbigniew Religa, the pioneer of Polish transplantology, made the first successful heart transplant in Poland [53]. It became obvious that patients waiting for transplants needed a pump that would replace or support their heart until they found a donor. The eighties in Poland were economically extremely difficult because the slowly decaying and crisis-plunged communist system firmly held citizens behind the Iron Curtain. The result was limited access to modern medical equipment. For this reason, Professor Zbigniew Religa independently appointed a team in which he engaged four key collaborators: Romuald Cichoń, Zbigniew Nawrat, Roman Kustosz and Piotr Wilczek. These people were key figures that still carry on the original mission to this day. In fact, the foundation grew up in opposition to LMDMs. It focused on the development of modern devices at a fraction of the price of those available in the United States, for example. The FCSD produced not only more cost-effective equivalents but, above all, innovative instruments, starting from the sketches to research, to implementation, and developing clinical procedures. This genesis of the project is responsible for the esteem that the FCSD enjoys today, not only in the medical environment but also in society in general. LMDMs relate to the FCSD with sympathy and do not try to aggressively take over the areas of the Polish medical market in which the FCSD operates. Of course, the good developed in the FCSD can and should serve not only Polish but patients in general. For this reason, the FCSD formally secures the availability of devices on the Polish market, and at the same time, tries to expand internationally. However, this is a very fresh initiative, and only after 25 years of the FCSD operation there is a need to contact and cooperate with LMDMs. The details of these interactions are shrouded in trade secrets, but it is obvious that the foundation's position is built on hundreds of lives saved [54, 55], over 40 patents [56], and hundreds of scientific publications [51, 52]. Even despite such achievements, contacting LMDMs is not easy. The FCSD gains experience in this field. The three flagship medical products developed by the FCSD include extracorporeal heart assist pumps [54, 55, 57], valvular homografts [58], and surgical robots [59-64]. So far, over 1000 extracorporeal heart assist pumps have been created. It is not possible to estimate the monetary profit associated with the production. The financing of the pumps was carried out by the FCSD and its subsidiary company, Intracordis, on a nonprofit basis as part of a medical procedure financed by the Polish Ministry of Health. However, these devices were used to saving lives $[54,55,57,65-68]$ and have been used in 6 major cardiac surgery centres in Poland [30]. Recently, the mechanical extracorporeal heart assist systems POLAVAD and POLCAS have changed their brand name to ReligaHeart. The ongoing clinical implementation includes pumps ReligaHeart EXT $80 \mathrm{ml}$ and pediatric pumps ReligaHeart PED 45, 30 and $20 \mathrm{ml}$. The stented homographs, ReligaValve, were very close to commercialization; the FCSD developed technologies for manufacture and adaptation to the needs of pediatric patients. The daughter company, Homograft FRK, as part of the so-called tissue bank, deals with their distribution [58]. Despite the huge clinical success of the device, the number of tissue donors limits their availability.

Surgical robots are an area where the cooperation of LMDMs will be particularly important due to the huge cost of clinical implementation. In this regard; the FCSD conducts a wide information campaign and popularizes its solutions through publications in specialist journal Medical Robots Methods [59, 69] and also via organizing annual events. For example, the conferences BioMedTech Silesia, Medical Robots or Cardio Surgeon Workshops have attracted over 1000 participants and widespread media interest. Moreover, FCSD has produced several patents.

Until now, these activities have not led to full-scale collaboration with LMDMs, or IP purchase proposals. However, a frequent meetings are held on exchange of views and the joint determination of steps and goals. It should be mentioned here that the most effective channel of 
information transfer, and thus the best way to contact LMDMs, were publications in magazines with a highimpact factor, to which the FCSD was repeatedly invited $[59,60]$. Interestingly, during publication effort, it was noted that editors and reviewers exert a subtle emphasis on the disclosure of certain technical issues, which were not essential for the article. Of course, these are the normal procedures because the editor knows and anticipates the needs of its readers, including experts from LMDMs.

The first step in the development strategy for robots was to raise funds from the National Centre for Research and Development in Poland (NCRD). Thanks to the funding obtained from the NCRD and financial support of the sponsors, the FCSD constructed several prototypes successfully used for in vivo and in vitro assessments. During the last few years, thanks to the multiple programs funded by the European Union, the FCSD improved the machine and developed an octopuslike robot that exhibits variable controlled rigidity and geometry of the tools to be used by surgeons [64, 7073]. At this stage, the FCSD is describing their knowhow and licensing agreements to launch the series of robots known as Robin Heart with the assistance of an external entity. The entity will be selected based on competition between several industry partners, which will be responsible for international expansion.

Bearing in mind the above experience in the field of promoting scientific studies and in the implementation of medical devices, the FCSD proposes the following recommendations:

(I) Close cooperation with prominent doctors is necessary because they hold the best knowledge on the actual needs of patients.

(II) It is necessary to obtain and maintain public support, seek to acquire friends and associates in the disciplines of mathematics, physics, chemistry, and biology.

(III)You need to consider the advantages of operating in developing countries where LMDMs technologies are less available, and the need for cost-efficient solutions gives you room for manoeuvre.

(IV)Identify the specific niche and need of the patient.

(V) Contact LMDMs when the technology is at the peak of its capabilities, so that LMDMs are the most eager to pay.

\section{Eng. Tal Golesworthy, C Eng MEI MRSC, Exstent Itd. Tewkesbury, UK}

Golesworthy invented the ExoVasc Aortic Root Support, which is an implant that supports the aortic root when it has become dilated and weak due to genetic conditions, eg. Marfan syndrome. Golesworthy was the first patient to be implanted with the ExoVasc, and more than 190 patients have benefited from his device since. Golesworthy is not only a successful inventor and entrepreneur but also contributes to the medical devices development field by providing public lectures. In these lectures, he conveys a honest description of the obstacles that may be encountered when proposing new solutions to conservative clinical environments [74].

Golesworthy started the personalized external aortic root support (PEARS) project in March 2000 when he had dilated to $5 \mathrm{~cm}$ and realized he had a substantial health problem. He attended the Marfan Association Information day at St George's Hospital and there he listened to Professor Tom Treasure's presentation on Root Replacement. He engaged Professor Treasure in conversation regarding scanning, CAD modelling, rapid prototyping and manufacturing the bespoke external supports. Currently, PEARS is morphing to a small/medium-sized enterprise. So far, 398 devices have been prepared for implantation. The implant is customized to the specific anatomic morphology of the patient, so each patient is supplied with a minimum of two devices, one acting as a backup for unpredicted circumstances. Golesworthy overcame many obstacles along the way. However, the most challenging was not associated directly with the device. Firstly, cardiologists and surgeons are a group of professionals with extremely busy schedules. One needs to be persistent and patient to gain their attention. Furthermore, even if offered the best options, patients may remain reluctant to try a pretty innovative device. Time and trust are needed to explain the advantages of a highly customized product against off-theshelf alternatives. To manufacture the customized product, non-anonymized patient data are necessary. This is a challenge to hospital bureaucracies since patient confidentiality is a priority for hospital administrations.

Moreover, hospitals are obliged to adhere to standards and procedures, therefore even the most attractive alternative to well-known solutions is taken with moderate enthusiasm. Personalized medical devices are not attractive to LMDMs, who are naturally more focused on mass production. The PEARS team sought funding from major heart research charities, however, no financial assistance was provided. PEARS had, therefore, to be funded by the formation of a UK Limited Company and raised the share subscriptions from High Net Worth Individuals.

Both regulatory bodies to which PEARS needs to refer (MHRA and NICE) have been conspicuous by their limited interference. Having a leading opinion formerly on the team is not a warranty of smooth overcoming of the above-mentioned obstacle. The expertise of scientists involved in the PEARS project provides much higher benefits than their fame and esteem. For example, the PEARS team includes Tom Treasure and John Pepper. They are both prominent members of the scientific community, 
however, journals related to cardiothoracic surgery in many cases dismiss their articles. Importantly, neither Professor receives remuneration from the PEARS project. To sum up, Golesworthy presents proof that the development of novel medical technology may occur without LMDMs. Highly customized products to which mass production does not apply may especially be an attractive market niche for small and medium entrepreneurs. That activity requires a relationship to clinicians which will support the new solution offered to the patient.

\section{Feedback from/about technology transfer centers Ronald J. Korstanje is a program manager and business development manager at Dutch polymer institute (DPI)}

The DPI was established in 1997 as an institution founded by industry. The academia joined DPI soon after. Currently DPI coordinate collaboration of about 30 industry entities (including AkzoNobel, BASF, Bayer, Evonik, and others) and research groups. The most prominent successes in term of the projects that led to the commercial products are temperature-responsive films on windows enhancing light reflection [75], ultra-high-molecularweight polyethylene [76] which is useful for manufacturing the ropes, cable and composites system and light and electric impulse responsive materials for cleaning the surfaces. In total, about 50 commercial products were developed or significantly improved thanks to the knowledge obtained within DPI. The largest, successfully overcame, obstacle was that researchers described the invention without consulting with the industrial partner which weakened the commercial strength of the patent. Currently, the preparation of innovation disclosure involves both the scientist and the industrial collaborators. This makes the patent more comprehensive and enhances information exchange. As an industrial partner of DPI, the entity is charged by fees. The funds are released to research teammates based on the progression of the given project and agreed milestones. The entire research process is orchestrated by industry site, which is responsible for framing the programs, projects and controlling its execution. To attract the researchers, DPI issues open calls for proposal. However, the industrial partner may shortlist scientific groups that they would like to invite for collaboration. Whenever a given product requires the approval of any regulatory body, the industrial partner is in charge of obtaining it. The most efficient way of communication is a joint meeting in which both science and industry representatives participate. The typical reward for developing innovation for researchers associated with DPI is enhancing financial support of further projects. The work on innovation disclosure, which usually takes 2-3 months, runs in parallel to writing a scientific article to avoid delays in literature communication. If a few entities are interested in commercializing the same DPI patent, they share IP and focus on a specific application field.

In the case of a scientist who is not involved in DPI framework, but is willing to contact DPI partners, the most efficient approach would be to provide DPI with a patent or patent application. DPI will consider its value and distribute the idea to the industrial associates. Optionally an NDA can be established, however, the drawback is the NDA's insufficiency to cover all aspects that must be addressed. The inquiries via DPI portal are welcomed [77].

Obviously, the experiences of DPI are not directly related to medical products such as a heart valve. However, it seems that an industry-driven initiative to collaborate with academia may be a good solution to enhance ideas/knowledge flow in a controlled, organized manner beneficial to all involved parties.

\section{Insider experience with Qatar Foundation technology transfer strategies}

The corresponding author of this review has 8 years of experience in conducting research and developing innovations in Qatar. He was associated with several local research institutions including WCM-Q, QCRC, Sidra Hospital, and QSTP. His work has been described in multiple scientific articles [2-7] and innovation disclosures (ID). His experiences in the development of in situ engineered heart valves may be presented in the context of the scientific and business relationship in Qatar.

The vast majority of research activities in Qatar are coordinated by Qatar Foundation (QF). The basis of the QF mission is the development of a knowledge-based society and through intellectual property (IP) to achieve nationwide, economic independence from natural resources. The most popular type of QF research grant is National Priorities Research Program (NPRP) administered by Qatar National Research Fund (QNRF), which usually provides $700 \mathrm{~K}$ USD for 3 years, $65 \%$ of which is to be spent in Qatar. NPRP is strongly oriented towards obtaining marketable patents, therefore cooperation with a business entity is practically mandatory in order to receive financing.

The QF strongly adheres to the chosen research strategy [78]. The researchers need to adapt their projects to QF requirements [79]. It is an inherent privilege of the founder to identify research goals, and the disciplines that arise from QF "hot spots" practically have no chances to be supported. This is the case for the Qatar heart valve program carried at Qatar Cardiovascular Research Center (QCRC) which was dispensed.

The entire ownership of any IP generated within QF belongs to the foundation, and the researcher can be rewarded with up to 1 million USD (terms and conditions apply). It should be noted that QF avoids sharing ownership of intellectual property, which often limits 
international interactions and cooperation with nonassociated QF inventors.

The most influential branches of the local industry are the gas and oil sector. Also, the construction industry and aluminium production facilities are represented, and there is a growing interest in agriculture and local food production. High-Tech companies, the natural consumers of academic innovations, operate under the umbrella of Qatar Science \& Technology Park (QSTP). For example, Exxon, Total, Shell, Vodafone and many other entities are present in the technology park.

A scientist who seeks to present his solution to an industrial partner has several paths to choose from. It may involve the industry partner in applying for an NPRP grant, to which the partner will make a financial and intellectual contribution.

The second option is the Intellectual Property and Technology Transfer (IPTT) office. The researcher associated with QF must log into the IPTT portal [80], provide a brief description of the invention, its development phase, personal data, and IP ownership statement. After a few weeks or several months, the inventor may be invited to a hearing with an IPTT representative. This experience is usually very positive and fruitful. IPTT officers are openminded, competent and professional. After the feedback is provided by the researcher, the officer submits the application for the approval of the board of directors to initiate the patentability check. This procedure is outsourced to a professional patent office, for example K\&L Gates LLP. The feedback provided is comprehensive, and if the final recommendation is negative, the researcher knows how to improve or adapt the recommendation issued. In the case of a positive recommendation, the patent will be granted, and the researcher may receive significant financial support from internal sources of IPTT to further improve their solution.

An additional option to find an industrial partner is QSTP, which identifies itself as "a technology hub for innovation.” QSTP coordinates several programs supporting the commercialization of innovation at various stages of development. This applies to accelerator programs devoted to the study of the market value of ideas. However, it should be mentioned that QSTP is offering training rather than financial assistance. At the current point, the efficiency of the above described intellectual property management system is not easy to estimate. This is because QF does not release to the public domain the information on business initiatives related to owned patents.

\section{Feedback form LMDMs}

Stanton J. Rowe, chief science officer and corporate vice president at Edwards Lifesciences in Irvin, calf

Stanton Rowe has been the chief scientific officer of Edwards Life Sciences since 2008 and corporate vice president of advanced technology. Edwards Life Sciences is a global leader in patient-focused medical innovations for structural heart disease. Rowe is also in charge of establishing a platform for collaborations with the world's leading researchers and clinicians to address unmet healthcare needs, including reliable HV prostheses. For that reason, his input is exceptionally important to the matters discussed in this manuscript. Below an interview with him is provided.

How can scientists identify the problems that are, at a given moment interesting to the industry partner?

Like any other scientific endeavour, listening and observation remain critical to industry and to you as a scientist. You are going to work for years on the problem, just like we will. Therefore, we need to ask the fundamental question: "Is the question or the problem I am trying to address significant enough for the time, effort and risk involved?". This fundamental question is asked in industry and I do not think it is different for a scientist. Ultimately, we all want to have an impact on patient's health. Fortunately, when we look at heart valves, it is easy to identify the fundamental issues. Not every $\mathrm{HV}$ lasts for the lifetime of the patient. Mechanical valves may also require reoperation because of the risk of chronic coagulation.

Let's consider the following hypothetical situation: Our team, which is not associated with Edwards, developed a solution that solves the above-mentioned issue. What would be the most efficient manner of approaching LMDMs to get feedback and, ultimately, support?

Let me give you an example. I often get calls from Academic Technology Transfer Centers (ATTCs). Assuming that what they offer is in alliance with our strategy, the first question is how do you know that the solution is feasible? What feasibility work have you done? By feasible I mean that the mechanism behind the solution was described and proven; the effect of the solution must be proven to be repeatable and controlled. The key hypothesis must be effectively tested against safety and applicability. Unless you form a good sense of the solution feasibility, it is just an idea for the prototype. And it is not typically that interesting. You have to go beyond the idea to some level of proof. Therefore, make it feasible before trying to make it interesting.

Because your typical way of interacting is through Academic Technology Transfer Centers, please describe how they physically approach you.

We are trying to be present on ATTCs email blast list. However, 95 out of 100 things they send out do not fit. But, on occasion, some things somewhat fit, in which case a telephone call is made for further clarity on these. Unfortunately, most of the transfer people at ATTCs do not fully understand the technology they are promoting. The trouble then is to get to the people who understand the 
problem and technology which is actually part of a more fundamental challenge. The question most scientists need to ask is: "Can I develop a concept and scientific measures that are publishable so that I can better retrieve promotion and notoriety in my scientific field?" We, as the industry side, have no interest in that whatsoever. My concern is: "Do you have something that is practical which I can develop to significantly improve patient care?". Occasionally, academics may have some scientific questions that I have little interest in answering.

Could you provide an example of such questions from the field of heart valve tissue engineering?

For example, when you take autologous cells and implant them, a lot of effort is typically taken to monitor the gene expression to see how native tissue responds to the autologous implant. Frankly, this is not of interest to me. In my view, the important questions are: "Are the autologous cells biocompatible? Do the autologous cells survive? What happens to them over time? Do them actually reduce calcification risk? Does it grow? Does it survive, and if replaced, then with what? How does the vascular grow to supply nutrition to autologous implant?" I want to know about histology and natural history of the implant, but I am not interested in gene expression.

When contacting ATTCs, do you expect them to have a patent for the promoted solution, or is that unnecessary?

Typically, I would not communicate with them until they have filed the patent.

Please estimate with how many external entities and internal researchers you are currently collaborating?

When it comes to basic research, we have continuous collaboration with approximately six entities. However, collaboration with the surgeon and cardiologist is much more common. We currently published first in man experience with ten patients, while the idea for that product came from the outside surgeon. About $50 \%$ of ideas that come to market were made with clinicians or scientists. We prefer to call our internal researchers biomedical engineers, rather than scientists, and about eight hundred of them work with us.

With such strong internal forces, what pushes you to external collaboration?

There are two answers. Firstly, most of the ideas that come in are at a very early stage. Carrying out earlystage work may involve three to four people. To get to something that can be filed to the FDA (Food and Drug Administration) and obtain approval will involve three to 4 years of work, and hundreds of people. This includes not only $R \& D$ engineering but also quality engineering, manufacturing engineering, clinical research. This is how our "internal forces" are used.

The second answer to the question is that our ideas are not necessarily better than anybody else's ideas. The "not invented here syndrome" means that you would not get the most compelling product. I want to develop the most compelling devices that help a patient, and I have little interest in where the idea comes from. If it is from one of my engineers - it is fantastic; if it is from the surgeon - fantastic, if it is from the professor of bioengineering it is wonderful.

For the internally unsolved problem, did you ever seek collaboration with an external scientist?Yes, for example, if we are doing implants, I have to call a haematologist. We do not have a haematologist in my company; however, nobody understands what happens in the bloodstream better than these guys. So, several times a year, we will contact a specialist to refine very specific expertise. We often deal with universities, but in many cases we do not. Typically, we conduct our own research and then we will reach out by telephone call to discuss and propose a consultant agreement that includes confidentiality and assignment of an IP. The expert will be exposed to an IP that is our proprietary. If he/she invents something that is related to that, we must own it. For example, if I taught you how to make an autologous HV from human cells, in a way previously unknown to you, and you come up with an idea based on the IP that I gave you, then I should have ownership rights. Depending on what the issue we are trying to address is, it can be a one-year collaboration, other times it is few weeks. There is some expertise we have ongoing, for example, pathology. We do not have a resident pathologist. When we do tissue explants, or have an HV that would return, we routinely send the materials outside to a consulting group that provides constant expertise to us.

Please describe how you harvest the data from scientific literature?

I expect all my biomedical engineers from R\&D to attend the medical meetings and to read both medical and technical articles. If an interesting idea appears and depending on their place in the organization, the biomedical engineer may talk to their manager and through "chain of command", to me. The first step to evaluate the idea would be to reach out with a confidentiality agreement, so we can better understand and perform diligently on the external technology.

Could you name academic influencers in the field of $H V$ tissue engineering?

I believe there are about 50 prominent academics in this area around the world. I am not sure if I know them all. Again, I am not interested in where the best idea comes from, instead, I try to evaluate the ideas based upon their merits, not who brought them to me. Even university professors in a top university may not necessarily understand what is practical and needed in terms of getting something in the market. One of the big challenges is exactly that, professors that teach biomedical 
engineering may have never actually developed a product.

Have you ever experienced dishonesty from an academic partner?

When they present their idea, some people want to make everything possible. Actually, the people who have the most credibility when presenting an idea say: "Here is what we know, and here is what we do not know. And what we do not know, we think we can do by doing these things. And here is what the risks are, and here is what we think about the risks". If you just stand up and say, "everything is perfect" it seems a lot less credible.

Would you like to add something that you believe is important that I have not asked?

Well, I will add, when you are talking about scientists, one of the challenges that I have faced over the years are obstacles in licensing technology. Scientists can often have unrealistic expectations, due to a limited understanding of the economics involved in product development.

Of course, this manuscript is a step on the way to overcoming these issues. However, if you feel that scientists are not able to interact efficiently, then is it not the job for the industry to educate them on that particulate matter?

I have been on a mission along these lines for several years now. I work with several bioengineering schools. I have done lectures at biomedical engineering societies. I am the person who is trying to indicate to biomedical professors, what we (the industry) want. When you train your biomedical engineers, you give them the skill set that they need to have. To me, the biggest travesty in the world is to produce a student who has spent four to 5 years of their life doing a degree and cannot compete for a job at the end.

\section{Ronan Rogers, new product development director at Medtronic}

Mr. Ranan Rogers is an R\&D Director with responsibility for new product development portfolios in the areas of coronary, hypertension and cardiac rhythm and heart failure. He is also a member of the Medtronic Site Leadership Team at Parkmore, representing R\&D and New Product Development. Rogers clarified that his responses are restricted to Medtronic facility at Galway, Ireland.

Medtronic is currently collaborating with four external research entities. The company is very active in the acquisition IPs, thus, the majority of ideas transferred to products were obtained externally. The company employs about 350 biomedical engineers in $R \& D$ and the annual budget for that division is approximately 70 million USD. When it comes to collaboration with academic partners, the largest obstacle is developing translational research and meeting agreed on project milestones and timelines. Medtronic is actively seeking collaborations, especially with clinicians. Various channels are utilized. Medtronic's Physician Services Teams, the relevant research centres, and marketing division are all responsible for establishing collaboration and information flows. Partner physicians are usually required to sign a standard confidentiality and nondisclosure agreement. If needed, adjustments of the NDA can be made upon the legal team review and approval. The company has a dedicated team that screens the literature for significant articles, however, this personnel are not exposed to interaction with the public. Typically, relationships with clinicians and external researchers last many years, and this strategy pays with a positive outcome, and with no record of negative experiences. Medtronic does not follow any influencers and evaluate new ideas based on their merits. Research and Development division does not carry direct negotiations of remuneration for intellectual property of the external scientists. Instead, specialized units of the company are in charge of that task. Medtronic does not provide a database of their patents related to their products. Rogers identified Medtronic's website [34] and conference proceedings as the best way of learning the current company needs and interests. For the external innovator, there is no step-by-step guide to gain the interest of the company, however, all ways of contacting (personal, email, via conferences, through collaboration projects) are welcome and may pay off.

To summarize the above-provided feedback, for the benefit of the academic inventor, while searching for interaction with Medtronic, the best way would be to approach a clinician that has a record of publications that describe the performance of Medtronic's, prosthesis [81-85].

\section{Feedback from IP-related policy and legislation developer; Richard O'Kennedy, Vice-President for Research at $\mathrm{HBKU}$}

Professor O'Kennedy was Scientific Director of the Biomedical Diagnostics Institute at Dublin City University (DCU). He is President of the London International Youth Science Forum and President of the Institute of Biology of Ireland. He was a member of the Industrial Research and Commercialization Committee of Enterprise Ireland. He has carried out many collaborations with industry, has 7 patents, multiple licenses and many of his reagents/innovations have been licensed and commercialized. He has a major interest in innovative approaches to Healthcare.

Why did you come to Qatar and for how long have you been working with us?

I was approached to come here, originally to be involved in the Qatar Biomedical Research Institute. When I came here, they asked me to be Vice President of HBKU and subsequently the Vice President for Research Development and Innovation. That includes implementation, 
which is particularly important for the topic of your manuscript. What brought me here are two things, mainly. One is the vision of Her Highness Sheikha Moza bint Nasser. Furthermore, when I came here, I was very struck by the fact that they had an excellent overall vision of what they wanted to achieve. I saw the development of Education City, HBKU, the institutes and the infrastructures that were built around them. I said this was a place where you could accommodate and develop ideas.

In Ireland, I was involved in development, particularly biopharma, but also IT because Dublin City University (DCU) was all about it. We built the university from 0 to 17,000 students. It took 35 years. We started from scratch with very few resources. Mainly, we were getting some governmental and international foundation support. I wanted to build on this experience. That can be done here but a lot faster. It has been 19 months since I started working here.

What are the IP management tools and procedures developed in Ireland/UK that you wish to implement in Qatar?

To address this question, we need to refer to the context. When I started in Ireland with a pre-university, at that point we were not allowed to start companies. The IP was not on the agenda. I got the first patent through the state. In the last 8 years, the DCU has more IP outcomes than any other university in the country. What I want to have here is a set of enabling legislation for IP and the individuals who are developing it. This is necessary to enable the individuals to get their ideas to commercialization. This is already in development. We have a very straight IP group, and we look at all the mechanisms we will need to enable the commercialization.

A transferable solution that deserves implementation in Qatar is an example of the Brighton project. It is about interfacing the digital technology and social humanities which yielded multiple successful companies. The crucial areas in which we hope to merge efforts of QCRI, Hamad hospital and other local entities is digital health and artificial intelligence. What we are missing now are the members of the team with experience in business development activities and investment expertise.

What are Qatar-specific challenges related to IP management?

I did not encounter any challenges that would be extraordinary or new to me. One of the things that was very important in Ireland was Knowledge Transfer Ireland. In this system, the rules and regulations were the same for each institution. Institutions have their role, but they need to also stay in line with national strategy. The central office manages the system and works closely with each entity that has an internal sub-office. Suboffices are part of universities, but they are strongly affiliated with central office. The central office has a capacity to provide some funding for IP development coordinated by sub-offices. I had a key role in developing that system in Ireland and I wish to implement the same element in Qatar. My office manages this task, but I want all entities - HBKU, research institutes - to have their own sub-offices with an assigned focal point. You need somebody who focuses every day on bringing management on board with how we can get ideas to/from individuals (researchers, academic staff), and bring that to the next level. And that is where QSTP comes in.

What are the currently available tools for the QF researcher who wishes to commercialize the research output?

There are two pathways. The first one is for the piece of new technology. For this, we have a product development fund, with which we may help you to go from the basic concept to the next level. If that succeeds, we have a number of other options including training. Some of them we are currently revamping. We are also facilitating the involvement of entrepreneurs. So, researchers with specific technical skills can act as a chief technical officer, while the entrepreneur provides business and marketing product development skills. The researcher can especially count on institutional expertise in IP. If the researcher wants to take the idea to another stage, a number of questions need to be addressed. For example, what is an ideal environment for the individuals who wish to spend their time on research commercialization? We are working on the improvement of the HBKU regulation to enable researchers to take some time off. At this point, the researcher needs special care and attention since they are going to get involved in potentially risky circumstances. In the next phase, we can involve an angel investment or our technology development fund, which for the next 5 years is 10 million USD a year. Involving the company to get investment or license fees is the moment where centralized common interinstitutional rules need to be followed. Following one specific scenario when dealing with external entities is crucial to reach a win-win situation where everybody benefits, especially the founding agency, entrepreneur and institutions that pay wages. This is the way it could be done and has been done before.

What improvements would you recommend to the Qatar IP management system?

We need to look more closely at the issue of risk. Studies show that most people do not like taking risks. Here, if you get an investment and it does not work out, the penalty can be serious. The one thing we have to do is to develop legislation to protect those who made a real and documented effort but failed to commercialize the product. In the best places in the world, the success rate of startups is about 1 in 10. I want to create an 
environment where we can increase the success rate with the right support, such as training on various types of funding. But also, we need to make sure that legislatively the person taking the risk would not be penalized. In the USA, you are almost expected to fail at the first commercialization attempt, while in Qatar, failure is strongly negative and potentially harmful. We should look at the failure as a mechanism of learning. Usually, people who failed once won't fail twice. And even if they do fail, what they have learned in the process may enable them to be much more successful later.

Moreover, there is scope for flexibility in regard to QF ownership of IP generated via NPRP funding. If the cost comes out of QF, this needs to be recognized by share of IP whenever an external founder invests financial resources in the collaborative project.

The extensive regulation and legislation may hinder the progress of research. Should Qatar legislation be more open to clinical trials and animal testing?

If you wish to go worldwide with your product, for example with medical devices, most definitely you will have to get FDA certification. We always have to make sure that the patient is very well protected. Furthermore, due to the limited population of Qatar, you may need to go outside with large clinical trials. On the other hand, the Qatar population is well-characterized from the genomic side, so you may precisely target a group of patients that will benefit from your system. In any case, the improvement of Qatar legislation goes in the direction of meeting the highest possible and worldwide recognized standards.

When can we expect the first product or service based on QF-owned IP to hit the market?

For the last 12 years, most of the funding has gone into research. A lot of resources before were put in funding but mainly on the educational side. If you look at the overall impact of Qatar-based research, about $85 \%$ meets the international standards. This is remarkable given the time frame and the investment. If you are building a house, the first thing you build is a foundation, and to put the roof on, you first need to build the walls. That is what we have been doing. We are building a good, strong foundation and the walls. But now, to get an outcome of that, it takes time. Let's also consider that some facilities reached their operational capacities only a year ago. Thus, we need to be realistic about expectations. For example, in some areas, QCRI is recognized as a world leader. Now it is the moment to exploit the ideas developed there. We have a good infrastructure for research thanks to investing in people. Now, we need to do the same for commercialization. Researchers are good at commercialization, but it is not their primary training, so we need the second layer of people. We have to develop entrepreneurs. Next year you are going to see significant startups launched.

Would you like to share any additional feedback to readers?

It is important, especially, for the international audience to convey the message that we are really going to push forward the commercial aspect of the research. We have a good technology park with 40 companies out there. We offer good training for entrepreneurs about available investment funds. We have top-class research and facilities. If you look at Qatar, it is an incredibly safe country, the leader of empowerment of women, winner of Asian cup 2019 football and host of FIFA-WC 2022. Geographically, it is very well placed for the middle east, far east and for Europe. It is recognized internationally and politically stable. Beyond the universities based in education city, we have Qatar University and multiple other entities. It is a world-class ecosystem that we want to make sustainable and diversified. To summarize, it is a wonderful place for companies to come, set up and participate in the next generation of digital technologies such as digital health and artificial intelligence.

The feedback provided by Prof. Kennedy from the perspective of local researcher/innovator has a few critical aspects that call for further comments. Firstly, the vision, determination and enthusiasm towards improving IP management solutions in Qatar is worth organic support from the prospective beneficent/system users. The proposed solution, namely changes in legislation, changing attitudes towards risk management, developing entrepreneurs and merging them with research, are examples of the top-down strategy. The bottom-up approach, which also has its advantages, is slightly less exploited. Taking the analogy of building the house, the best moment to audit/evaluate the construction is when the building arises. Actually, it is too late to improve after plastering and painting. It is good practice to involve the final users form the early stage of home production and receive the feedback. To give an example, failure is acceptable only if the documented effort was made to succeed. Otherwise, one may reach for initiatives designed to fail or abuse the system to get financial advantages. The tools are needed to distinguish between legitimate effort and fraud.

The second important consideration must focus on the speed of response from the institutional patent office and quality of feedback. The IP office should be able to provide an executive decision to the researcher regarding QF interest in processing with patentability check and patent. The decision should be made in a reasonable time frame. In case QF is not interested in patenting the given solution, the researcher should be allowed to publish the results in a scientific journal. When rejecting the idea, as a matter of courtesy, the patent office may provide a brief justification of decision. This will help the 
researcher to learn and make better adjustments in future attempts. Guidance for proceeding with patenting efforts could be distributed to the researchers. It is excelent that the technology development fund for the next 5 years is 10 million USD a year, but it would be even better if we learnt how to physically obtain this support.

Finally, there is a need to develop the tools depending on which parties are involved; researchers, the committees and the bodies that decide on which idea deserve or not to be supported, know each other and understand the needs and interests.

\section{Discussion}

Because there are formal law restrictions related to launching medical devices such as an HV, it seems that only LMDMs have enough resources to marketize any novel solutions. LMDMs are difficult to reach by the individual researcher. Specialized academic technology transfer centres have a better chance to grab their attention and enhance/moderate interactions. The entities searching for LMDMs' attention must possess the intellectual rights for the solution they are trying to promote. Ideas alone would not be enough for meaningful consideration. Developing NDA agreements require law expertise, and specialized academic technology transfer centres have advantages in providing it. LMDMs do not share the emotional involvement of the researcher. The researcher must stay open for heavy criticism and can gain trust and respect by admitting limitations rather than focusing on strong points of the solution. The national health organizations are a valuable source of information that may be utilized in business planning. Obviously contacting them must be formalized and could be time-demanding, however, it pays off. Noteworthy, NFZ was quick to respond, especially considering the professionalism and value of the prepared report.

The key discrepancy between academic researchers and industry representatives lies in their attitude towards experimentation that yields in innovation. For the researcher, innovation is the culminating point associated with satisfaction and joy. If the proposed solution is interesting for LMDMs, the moment of admitting it is the start of a long and difficult journey. Implementing new technology, especially in HV, will involve hundreds of people and enormous financial effort, while the outcome is uncertain. From this perspective, the role of a researcher collaborating with an industry partner is to act in a way that shows long-standing dedication and offer the support as a loyal, reliable and keen to learn member of the team in a prospective project. A reasonable alternative is to approach LMDMs via clinicians with whom they collaborate. The names can be derived from the Conflict of Interest Disclosures section of articles [86].
Finally, we need to take ownership of the fact that the modus operandi we have exercised so far was suboptimal. We planned to supplement already developed solutions with the result of the animal test. We hoped to be supported by investments found to obtain a patent that would be sold to LMDMs. However, it becomes obvious that LMDMs preferred interaction with academic technology transfer centres and not with individual researchers. Overall, this indicates that researchers should pay special attention to being affiliated with universities with a strong record of intellectual property commercialization.

Together, Edwards and Medtronic have over 1000 biomedical engineers supported by a dedicated team to screen the scientific literature, and, therefore, we propose the following exercise. Whoever will email the corresponding author with a declaration that article was read would be recommended by the corresponding author to be promoted. The email addresses obtained in this way will be confidential and not used for further communication. The aim of the exercise is to check the efficiency of literature screening in LMDMs.

\section{Conclusions}

The commercialization of research output is a complex process that in some critical aspects does not depend solely on the researcher himself. An industrial party may overlook even the most promising ideas supported by strong experimental evidence, lacking the support of institutions and agencies such as a technology transfer centres. Also, as emphasized by prof. Kennedy, involvement of scientists in a business project takes them, at least temporarily, outside the regular academic environment. It may be "not everybody's cup of tea". Another limitation of the academic world that needs to be addressed is the reluctance to report the unsuccessful attempts. Recognizing failure as a valuable educational experience seems justified.

However, why should the lesson benefit only the individual? We need to determine how to describe such experiences in a way that allows specific studies, which would lead to an improvement in the success rate of startups. As many examples show, commercial successes are often a combination of hard work and ordinary luck. In other words, the key to success is to be in the right place at the right time. Optimizing efforts to increase work efficiency was the domain of science long before Henry Ford's improvements. Luck is probabilistic, so chances of success increase with the number of attempts. From this perspective, agencies that support innovators may consider distributing small funds to many, instead of a tremendous support for a few. This observation is not conducive to cost-intensive strategies such as the development of new medical devices. However, the findings of this article do not necessarily support our innovations. 


\section{Abbreviations}

ATTCs: Academic Technology Transfer Centers; DPI: Dutch Polymer Institute FCSD: Foundation of Cardiac Surgery Development; FDA: Food and Drug Administration; HV: Heart valve; HVTE: Heart valve tissue engineering; ID: Innovation disclosures; IP: Intellectual property; IPTT: Intellectual Property and Technology Transfer; LMDMs: Large medical device manufacturers; NCRD: National Centre for Research and Development; NDA: Non-disclosure agreement; NFZ: Narodowy Fundusz Zdrowia (Polish); NPRP: National Priorities Research Program; PCL: Polycaprolactone; PEARS: personalized external aortic root support; QCRC: Qatar Cardiovascular Research Center; QF: Qatar Foundations; QNRF: Qatar National Research Fund; QSTP: Qatar Science \& Technology Park

\section{Acknowledgements}

The authors thank Ziyad M Hijazi (Sidra), Ronald J. Korstanje (DPI), Stanton J. Rowe (Edwards), Richard Kennedy (HBKU) for providing an interview. We also thank Dariusz Zielinski, Kinga Skoczylas (Metronic, Poland), Ronan Rogers (Medtronic), Rhonda Hatch (Edwards) for their kind assistance in reaching the interviewees. We also thank the NFZ management and personnel Andrzej Jacyna, Daniel Rutkowski, Andrzej Pajączkowski, Marcin Czyżewskiand Barbara Adamczyk for their critical and valuable input into this manuscript, as well as the responders for their valuable contribution, and Aleksandra Liberska, Dorota Cibor, and Kat Korsonfor editing the manuscript. The authors also thank the anonymous contributors who helped to improve the manuscript by providing valuable reviewer comments.

\section{Authors' contributions}

AL - idea, writing manuscript, figure preparation, establishing contacts, conducting the interviews, interviews transcription, obtaining authorisations. $\mathrm{JB}, \mathrm{ZN}, \mathrm{TG}$, - provided critical information in the interview. DT - provided critical feedback on QF innovation activities and reviewed the manuscript. All authors read and approved the final manuscript.

\section{Funding}

The funding for this research were obtained from National Priorities Research Program NPRP12S-0302-190202. The Qatar National Library paid fees for making this article open access.

\section{Availability of data and materials \\ N/A}

\section{Ethics approval and consent to participate}

Not applicable.

\section{Consent for publication}

Not applicable.

\section{Competing interests}

The authors declare that they have no competing interests.

\section{Author details}

'Division of Sustainable Development, College of Science \& Engineering, Hamad Bin Khalifa University, P.O. Box 34110, Education City, Doha, Qatar. ${ }^{2}$ Nancy E. and Peter C. Meinig School of Biomedical Engineering, Cornell University, Weill Hall, Ithaca, NY 14853, USA. ${ }^{3}$ Foundation of Cardiac Surgery Development, Wolnosci 345a, 41-800 Zabrze, Poland. ${ }^{4}$ Exstent Limited, Theocsbury House, 18 - 20 Barton Street, Tewkesbury, Gloucestershire GL20 5PP, UK. ${ }^{5}$ Information \& Computing Technology, College of Science and Engineering, Hamad Bin Khalifa University, P.O. Box 34110, Education City, Doha, Qatar.

Received: 19 May 2019 Accepted: 9 September 2019

Published online: 22 October 2019

\section{References}

1. Gottland: Mostly True Stories from Half of Czechoslovakia - Mariusz Szczygiel - Google Książki [Internet]. [cited 2019 Sep 4]. Available from: https://books.google.com.qa/books/about/Gottland.html?id= CCMPAgAAQBAJ\&redir_esc=y
2. Wojciechowska D, Liberski AR, Wilczek P, Butcher J, Scharfschwerdt M, Hijazi

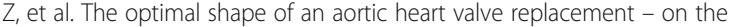
road to the consensus. QScience Connect. 2017;2017(3):1.

3. Liberski A, Latif N, Raynaud C, Bollensdorff C, Yacoub M. Alginate for cardiac regeneration: From seaweed to clinical trials, Global Cardiology Science and Practice. 2016;4. https://doi.org/10.21542/gcsp.2016.4.

4. Liberski A, Ayad N, Wojciechowska D, Zielińska D, Struszczyk MH, Latif N, Yacoub M. Knitting for heart valve tissue engineering, Global Cardiology Science and Practice. 2016;31. https://doi.org/10.21542/gcsp.2016.31.

5. Liberski AR. Three-dimensional printing of alginate: from seaweeds to heart valve scaffolds. QScience Connect. 2016:2016(2):3.

6. Liberski AR, Raynaud CM, Ayad N, Wojciechowska D, Sathappan A. Valve tissue engineering with living absorbable threads. Macromol Biosci. 2017; 17(5). https://doi.org/10.1002/mabi.201600196.

7. Liberski A, Ayad N, Wojciechowska D, Kot R, Vo DMP, Aibibu D, et al. Weaving for heart valve tissue engineering. Biotechnol Adv. 2017;35(6): 633-56.

8. Intelligent materials for in-situ heart valve tissue engineering | projects | FP7-NMP | CORDIS | European Commission [internet]. [cited 2019 Feb 6] Available from: https://cordis.europa.eu/project/rcn/110963/factsheet/en.

9. Kluin J, Talacua H, Smits AIPM, Emmert MY, Brugmans MCP, Fioretta ES, et al. In situ heart valve tissue engineering using a bioresorbable elastomeric implant - from material design to 12 months follow-up in sheep. Biomaterials. 2017;125:101-17.

10. Bouten CVC, Smits AIPM, Baaijens FPT. Can we grow valves inside the heart? Perspective on material-based in situ heart valve tissue engineering. Front Cardiovasc Med. 2018:5:1-10.

11. Reynolds MR, Lei Y, Wang K, Chinnakondepalli K, Vilain KA, Magnuson EA, et al. Cost-effectiveness of Transcatheter aortic valve replacement with a self-expanding prosthesis versus surgical aortic valve replacement. J Am Coll Cardiol. 2016;67(1):29-38.

12. Beresniak A, Sabatier B, Achouh $P$, Menasché $P$, Fabiani J-N. Costeffectiveness of mitral valve repair versus replacement by biologic or mechanical prosthesis. Ann Thorac Surg. 2013;95(1):98-104.

13. McCarthy Fenton H, McDermott Katherine M, Saif A, Jay G, Hoedt Ashley C, Dale $\mathrm{K}$, et al. Cost of Transcatheter aortic valve replacement in Medicare patients. Circ Cardiovasc Qual Outcomes. 2015;8(suppl_2):A22.

14. Tam DY, Hughes A, Fremes SE, Youn S, Hancock-Howard RL, Coyte PC, et al. A cost-utility analysis of transcatheter versus surgical aortic valve replacement for the treatment of aortic stenosis in the population with intermediate surgical risk. J Thorac Cardiovasc Surg. 2018;155(5):1978-1988.e1.

15. Huygens SA, Goossens LMA, van EJA, Takkenberg JJM, Mölken MPMHR. How much does a heart valve implantation cost and what are the health care costs afterwards? Open Heart. 2018:5(1):e000672.

16. Manolis AS. Transcatheter aortic valve implantation economics: a grisly reality. Ann Cardiothorac Surg. 2017;6(5):516-23.

17. Mabin TA, Candolfi P. An analysis of real-world cost-effectiveness of TAVI in South Africa. Cardiovasc J Afr. 2014;25(1):21-6.

18. Kuwata S, Maisano F. Looking to the future of mitral valve replacement. Eur Heart J. 2017;38(9):622-4

19. Fioretta ES, Dijkman PE, Emmert MY, Hoerstrup SP. The future of heart valve replacement: recent developments and translational challenges for heart valve tissue engineering. J Tissue Eng Regen Med. 2018;12(1):e323-35.

20. Kheradvar A, Groves EM, Goergen CJ, Alavi SH, Tranquillo R, Simmons CA, et al. Emerging trends in heart valve engineering: part II. Novel and standard technologies for aortic valve replacement. Ann Biomed Eng. 2015:43(4):844-57

21. Itd R and M. Aortic Valve Replacement Devices Market Size, Share And Trends Analysis Report By Surgery (Open, Minimally Invasive), By Product (Transcatheter Aortic Valve, Sutureless Valve), By End-user, And Segment Forecasts, 2018-2025 [Internet]. [cited 2019 Feb 6]. Available from: https:// www.researchandmarkets.com/reports/4582056/aortic-valve-replacementdevices-market-size

22. Intelligence AA\&. Heart Valve Repair and Replacement Devices Market Global Outlook and Forecast 2018-2023 [Internet]. Arizton Advisory \& Intelligence. [cited 2019 Feb 6]. Available from: https://www.arizton.com/ market-reports/heart-valve-repair-and-replacement-devices-market

23. Heart Valves Structural Heart and Endograft Technologies [Internet]. [cited 2019 Feb 6]. Available from: https://www.vizientinc.com/-/media/ Documents/SitecorePublishingDocuments/Public/2017_Heart_Valves Structural_Heart_and_Endograft_Technologies_Vol1.pdf 
24. Prosthetic Heart Valve Market by Type \& Region - Global Forecast 2022 | MarketsandMarkets [Internet]. [cited 2019 Feb 6]. Available from: https:// www.marketsandmarkets.com/Market-Reports/prosthetic-heart-valvemarket-245407958.html?gclid=CjwKCAiAqOriBRAfEiwAEb9oXXIMpQBsG9lh4 s3yiRV6a5EzxmjmZe62DrylYgaQE8JTBXrF7_f2FhoCwLYQAvD_BwE

25. Itd R and M. Prosthetic Heart Valves - Global Strategic Business Report [Internet]. [cited 2019 Feb 6]. Available from: https://www. researchandmarkets.com/reports/1824155/prosthetic_heart_valves_ global_strategic

26. Knowledge HW. New medical devices get to patients too slowly [Internet]. Forbes. [cited 2019 Feb 6]. Available from: https://www.forbes. com/sites/hbsworkingknowledge/2015/08/11/new-medical-devices-getto-patients-too-slowly/

27. Itd R and M. Transcatheter Aortic valve Replacement Market: Global Industry Analysis, Trends, Market Size and Forecasts up to 2023 [Internet]. [cited 2019 Feb 6]. Available from: https://www.researchandmarkets.com/reports/452 0809/transcatheter-aortic-valve-replacement-market

28. Rome BN, Kramer DB, Kesselheim AS. Approval of high-risk medical devices in the US: implications for clinical cardiology. Curr Cardiol Rep. 2014;16(6):489.

29. Demanding Financial Value In Valve Programs [Internet]. Cardiovascular Business. [cited 2019 Feb 6]. Available from: https://www. cardiovascularbusiness.com/topics/structural-congenital-heart-disease/ demanding-financial-value-valve-programs

30. Report on HV prosthesis usage in Poland [Internet]. Available from: http:// albert-liberski.eu/wp-content/uploads/2019/02/Copy-of-Copy-of-NFZ_Skan.pdf.

31. Kopczak L, Lee H. Hewlett-Packard Company DeskJet printer supply chain (A). Case GS-3A. Stanford, CA: Stanford Graduate School of Business. 2001.

32. Liberski A. Example of the survey e-mail [internet]. [cited 2019 Feb 7]. Available from: http://albert-liberski.eu/wp-content/uploads/2019/02/ Example-Invitation.docx.

33. Narodowy Fundusz Zdrowia [Internet]. Narodowy Fundusz Zdrowia. [cited 2019 Feb 6]. Available from: http://www.nfz.gov.pl/.

34. Medtroneic. Medtronic Patient Services [Internet]. [cited 2019 Feb 6]. Available from: https://www.medtronic.com/us-en/patients/patient-services.html

35. Patient voice | Edwards Lifesciences [Internet]. [cited 2019 Feb 6]. Available from: https://www.edwards.com/aboutus/patientvoice

36. Z-MED ${ }^{\text {TM }} \&$ Z-MED $\|^{\text {TM }} \mid$ B. Braun Interventional Systems [Internet]. [cited 2019 Feb 7]. Available from: http://www.bisusa.org/products/pta-ptv-balloons/z-med

37. Hijazi ZM, Homoud M, Aronovitz MJ, Smith JJ, Faller GT. A new platinum balloon-expandable stent (Angiostent) mounted on a high pressure balloon: acute and late results in an atherogenic swine model. J Invasive Cardiol. 1995;7(5):127-34.

38. Hijazi ZM, Geggel RL, Aronovitz MJ, Marx GR, Rhodes J, Fulton DR. A new low profile balloon atrial septostomy catheter: initial animal and clinical experience. J Invasive Cardiol. 1994;6(6):209-12.

39. Du ZD, Hijazi ZM, Kleinman CS, Silverman NH, Larntz K, Amplatzer Investigators. Comparison between transcatheter and surgical closure of secundum atrial septal defect in children and adults: results of a multicenter nonrandomized trial. J Am Coll Cardiol. 2002:39(11):1836-44.

40. Patel H, Holzer R, Cao Q-L, Hijazi ZM. Transcatheter Closure of Atrial-Septal Defects Using the Amplatzer Devices. In: Herrmann HC, editor. Interventional Cardiology: Percutaneous Noncoronary Intervention. Totowa: Humana Press; 2005. p. 161-78. (Contemporary Cardiology).

41. Suradi HS, Hijazi ZM. Percutaneous pulmonary valve implantation. Glob Cardiol Sci Pract. 2015:2015(2):23.

42. Holoshitz N, Kavinsky CJ, Hijazi ZM. The Edwards SAPIEN Transcatheter heart valve for calcific aortic stenosis: a review of the valve, procedure, and current literature. Cardiol Ther. 2012;1(1):6.

43. PICS Symposium [Internet]. [cited 2019 Feb 7]. Available from: http://www. picsymposium.com/.

44. Al Jazeera English. Qatar uses gene mapping in bid to improve national health [internet]. [cited 2019 Feb 7]. Available from: https://www.youtube. com/watch?V=xTP1J3sHLYw

45. By MASSDEVICE staff. Bankrupt NMT Medical sells intellectual property to W. L. Gore [Internet]. MassDevice. 2011. Available from: https://www. massdevice.com/bankrupt-nmt-medical-sells-intellectual-property-wl-gore/. [Cited 2019 Feb 7].

46. Cheung DY, Duan B, Butcher JT. Current progress in tissue engineering of heart valves: multiscale problems, multiscale solutions. Expert Opin Biol Ther. 2015;15(8):1155-72.
47. No donor required: 5 body parts you can make with 3-D printers [Internet]. [cited 2019 Feb 7]. Available from: https://www.forbes.com/sites/ robertszczerba/2015/06/17/no-donor-required-5-body-parts-you-can-makewith-3-d-printers-2/\#1d78c5fc7d55

48. Frendl CM, Butcher JT. Biomedical implant for use in fluid shear stress environments [Internet]. US20140350671A1, 2014 [cited 2019 Feb 7]. Available from: https://patents.google.com/patent/US20140350671A1/ en?inventor=Jonathan+T.+Butcher

49. Butcher J, Gould R. Method and device for evaluation of local Tissue's biological or biomechanical character [Internet]. 20130190597, 2013 [cited 2019 Feb 7]. Available from: http://www.freepatentsonline.com/y2 013/0190597.html

50. Butcher JT, Kang KH, Yeh K, Cheung PY, Hockaday LA. Method for specifying and fabricating an object, associated apparatus, and applications [Internet]. US20140052285A1, 2014 [cited 2019 Feb 7]. Available from: https://patents.google.com/patent/US20140052285/en?oq=Jonathan+T.+ Butcher

51. Foundation of Cardiac Surgery Development - publications [Internet]. [cited 2019 Feb 11]. Available from: https://frk.pl/publikacje-biocybernetyki.html

52. Zbigniew Nawrat - Director of the Heart Prosthesis Institute - PUBLICATIONS [Internet]. Zbigniew Nawrat. [cited 2019 Feb 11]. Available from: http://enawrat.eu/publications/.

53. The history of a picture that changed the world [Internet]. [cited 2019 Feb 7]. Available from: https://www.zmescience.com/other/great-pics/zbigniewreliga-picture/.

54. Religa G, Jasińska M, Czyżewski Ł, Torba K, Różański J. The effect of the sequential therapy in end-stage heart failure (ESHF) - from ECMO, through the use of implantable pump for a Pneumatic heart assist system, Religa heart EXT, as a bridge for Orthotopic heart transplant (OHT). Case study. Ann Transplant. 2014;19:537-40.

55. Kuśmierczyk M, Kuć M, Szymański J, Juraszek A, Kołsut P, Kuśmierski K, et al. Pulsatile-flow mechanical circulatory support (MCS) as a bridge to transplantation or recovery. Single-Centre experience with the POLCAS system in 2014. Kardiochirurgia Torakochirurgia Pol J Thorac Cardiovasc Surg. 2015;12(3):228-32.

56. Foundation of Cardiac Surgery Development patents list [Internet]. [cited 2019 Feb 7]. Available from: https://frk.pl/patenty-pracowni-sztucznegoserca.html

57. Litwiński P, Woźniewicz B, Religa G, Pastuszek M, Parulski A, Jasińska M, et al. Polish ventricular assist device (POLVAD) support for the treatment of cardiogenic shock in patients with myocarditis. Kardiochirurgia Torakochirurgia Pol J Thorac Cardiovasc Surg. 2006;2(4):33-40.

58. FRK Homograft [Internet]. [cited 2019 Feb 7]. Available from: https:// homograft.frk.pl/.

59. Nawrat Z. State of the art in medical robotics in Poland: development of the Robin heart and other robots. Expert Rev Med Devices. 2012;9(4):353-9.

60. Nawrat Z, Kostka P. Polish cardio-robot 'Robin heart'. System description and technical evaluation. Int J Med Robot Comput Assist Surg MRCAS. 2006;2(1):36-44.

61. Nawrat Z. Robot chirurgiczny Robin Heart: projekty, prototypy, badania, perspektywy. Śląski Uniwersytet Medyczny; 2011. 290 p.

62. Nawrat Z. The Robin heart story. Med Robot Rep. 2012;1:19-21.

63. Lis K, Lehrich K, Mucha $\measuredangle$, Nawrat Z. Concept of application of the lightweight robot Robin heart ('Pelikan') in veterinary medicine: a feasibility study. Med Weter. 2017;73:88-91.

64. Mucha $Ł$, Lis K. Force Feedback Sleeve Using Pneumatic and Micro Vibration Actuators. In: Soft and Stiffness-controllable Robotics Solutions for Minimally Invasive Surgery: The STIFF-FLOP Approach. Denmark: River Publishers; 2018. p. 251-62. (River Publishers Series in Automation, Control and Robotics).

65. Nawrat Z. Zbigniew Religa: an unfinished story. Int J Artif Organs. 2009; 32(6):315-7.

66. Nadziakiewicz P, Szyguła-Jurkiewicz B, Pacholewicz J, Zakliczyński M, Przybyłowski P, Krauchuk A, et al. Predictive value of models for end-stage liver disease score in patients with pulsatile flow POLVAD MEV left ventricular assist device support. Transplant Proc. 2018;50(7):2075-9.

67. Nadziakiewicz P, Borkowski J, Szygula-Jurkiewicz B, Niklewski T, Pacholewicz J, Zakliczynski M, et al. Right ventricular function in patients with left ventricular assist device support by pulsatile Polvad MEV and continuous-flow pumps Heartware and heartmate II. Transplant Proc. 2016:48(5):1786-90. 
68. Nadziakiewicz P, Szygula-Jurkiewicz B, Niklewski T, Pacholewicz J, Zakliczynski M, Borkowski J, et al. Effects of left ventricular assist device support on end-organ function in patients with heart failure: comparison of pulsatile- and continuous-flow support in a single-center experience. Transplant Proc. 2016;48(5):1775-80.

69. Rohr K, Fürjes P, Mucha L, Lis K, Radó J, Dücső C, et al. Robin heart force feedback/control system based on INCITE sensors: preliminary study. Med Robot Rep. 2015;4:10-7.

70. Małota Z, Nawrat Z, Sadowski W. Benchmarking for Surgery Simulators. In: River Publishers Series in Automation, Control and Robotics. Denmark: River Publishers; 2018. p. 309-23. (River Publishers Series in Automation, Control and Robotics).

71. Łukasz M, Lis K, Krawczyk D, Nawrat Z. The Design of a Functional STIFFFLOP Robot Operator's Console. In: Soft and Stiffness-controllable Robotics Solutions for Minimally Invasive Surgery: The STIFF-FLOP Approach. Denmark: River Publishers; 2018. p. 221-8. (River Publishers Series in Automation, Control and Robotics).

72. Arezzo A, Mintz Y, Allaix ME, Arolfo S, Bonino M, Gerboni G, et al. Total mesorectal excision using a soft and flexible robotic arm: a feasibility study in cadaver models. Surg Endosc. 2017;31(1):264-73.

73. Lis K, Mucha $Ł$, Lehrich K, Nawrat Z. RobinHand Haptic Device. In: Soft and Stiffness-controllable Robotics Solutions for Minimally Invasive Surgery: The STIFF-FLOP Approach. Denmark: River Publishers. p. 289-305. (River Publishers Series in Automation, Control and Robotics).

74. Golesworthy T. How I repaired my own heart [Internet]. [cited 2019 Feb 7]. Available from: https://www.ted.com/talks/tal_golesworthy_how_i repaired_my_own_heart

75. Liquid Crystals for Windows | Merck Global [lnternet]. [cited 2019 Feb 19]. Available from: http:/www.merckgroup.com/en/expertise/architecture/ solutions/liquid-crystal-windows.html

76. Endumax | Teijin Aramid [Internet]. [cited 2019 Feb 19]. Available from: https://www.teijinaramid.com/en/products/endumax/.

77. DPI Contact weebsite [Internet]. [cited 2019 Feb 7]. Available from: https:// www.polymers.nl/contact.

78. Qatar National Research Strategy (QNRS) [Internet]. [cited 2019 Feb 7]. Available from: http://www.qnif.org/en-us/About-Us/QNRS.

79. Oatar National research Fund 'NATIONAL PRIORITIES RESEARCH PROGRAM STANDARD', Request for proposals 12th cycle [internet]. [cited 2019 Feb 7]. Available from: https://www.qnrf.org/Portals/0/RFP-NPRP-S-12-Final_1.pdf.

80. Intellectual Property and Technology Transfer [Internet]. [cited 2019 Feb 11]. Available from: http://www.gfrdi.org/iptt.

81. Descoutures F, Himbert D, Radu C, lung B, Cueff C, Messika-Zeitoun D, et al. Transarterial Medtronic CoreValve system implantation for degenerated surgically implanted aortic prostheses. Circ Cardiovasc Interv. 2011;4(5):488-94.

82. Geisbüsch S, Bleiziffer S, Mazzitelli D, Ruge H, Bauernschmitt R, Lange R. Incidence and management of CoreValve dislocation during transcatheter aortic valve implantation. Circ Cardiovasc Interv. 2010;3(6):531-6.

83. Webb JG, Wood DA. Current status of Transcatheter aortic valve replacement. J Am Coll Cardiol. 2012;60(6):483-92.

84. D'Ancona G, Dissmann M, Heinze H, Zohlnhöfer-Momm D, Ince H, Kische S. Transcatheter aortic valve replacement with the $34 \mathrm{~mm}$ Medtronic Evolut valve. Neth Heart J. 2018;26(7-8):401-8.

85. Hellhammer K, Piayda K, Afzal S, Kleinebrecht L, Makosch M, Hennig I, et al. The latest evolution of the Medtronic CoreValve system in the era of Transcatheter aortic valve replacement: Matched Comparison of the Evolut PRO and Evolut R. JACC Cardiovasc Interv. 2018;11 (22):2314-22.

86. Shivaraju A, Michel J, Frangieh AH, Ott I, Thilo C, Schunkert H, et al. Transcatheter Aortic and Mitral Valve-in-Valve Implantation Using the Edwards Sapien 3 Heart Valve. J Am Heart Assoc Cardiovasc Cerebrovasc Dis. 2018;7(14) [cited 2019 Feb 7]. Available from: https://www.ncbi.nlm.nih. gov/pmc/articles/PMC6064864/.

\section{Publisher's Note}

Springer Nature remains neutral with regard to jurisdictional claims in published maps and institutional affiliations.

Ready to submit your research? Choose BMC and benefit from:

- fast, convenient online submission

- thorough peer review by experienced researchers in your field

- rapid publication on acceptance

- support for research data, including large and complex data types

- gold Open Access which fosters wider collaboration and increased citations

- maximum visibility for your research: over $100 \mathrm{M}$ website views per year

At BMC, research is always in progress.

Learn more biomedcentral.com/submissions 